\title{
Jurisdiction in the Territorial Hierarchical Administration Office: An Example of the Historical Land of Styria from 1186 to 1850
}

\author{
BORUt HOLCMAN \& GERnOT Kocher
}

\begin{abstract}
Division of administrative powers is the result of concrete decisions made by the supreme power holders (ius eminens) to be present in the daily life of an individual. Quarters, district offices (in Slovene: "kresije" [pl.]), counting offices, recruitment districts, and district boards were those agents of power that were used by the supreme power holder to ensure the common good through them. The holder's power originated from the supreme power holder. It was restricted by the degree at which he operated. According to the nature of things, the power was subordinated by the delegated competences, and they functioned on the principle of subsidiarity, or it was autonomous under control in the case of the Church. Pragmatism of each supreme power holder is reflected in observing the divisions in operation. They most frequently emerged from the controlled autonomy.
\end{abstract}

KEYWORDS: • jurisdiction $\bullet$ administration $\bullet$ institution $\bullet$ hierarchical character of bureaucratic apparatus $\bullet$ administrative history $\bullet$ Roman Catholic Church

CORRESPONDENCE ADDRESS: Borut Holcman, $\mathrm{PhD}$, University of Maribor, Faculty of Law, Mladinska ulica 9, SI-2000 Maribor, e-mail: borut.holcman@uni-mb.si. Gernot Kocher, PhD, Karel Franzes University Graz, Institut für Österreichische Rechtsgeschichte und Europä ische Rechtsentwicklung, Universitätsstraße 15, ResowiZentrum A1 und A3, A-8010 Graz, Austria, e-mail: gernot.kocher@uni-graz.at. 


\section{Introduction}

The administrative organisation of a certain space has always been the response to specific conditions. It is the result of the political (dynastic and legal), cultural, religious, and economic life. The historical development needs to be sought in wilful promotion of endeavours to achieve the common good ("gemeiner nutz") as the highest goal of the state. ${ }^{1}$ It does not depend on the level at which the country is organised (land, quarter, district office, counting offices, recruitment districts, municipalities, etc.). The goal is anywhere where the state operates. It is merely important that there is a complete space with established institutions (offices) with precisely defined powers, if possible, for all the areas of interest for the state (economy, security, finance, service activities, etc.). The competences of the power holders themselves are thus entirely autonomous (ius eminens) or subject to delegation (land dominions, quarters, district offices, towns (cf. Kambič: 2008, pp. 477) ${ }^{2}$, or they are autonomous under control (Church, cf. Kolar: 2008, pp. 3-31). According to their origin, power holders are original, i.e., they are appointed, or in modern times of democracy, some of them are also elected (Toplak, 2004: 1) ${ }^{3}$.

The administrative organisation and its powers are linked to costs. This organisation is one of the important components of governance. In the initial stage when costs were manageable, the entire administrative machinery was paid by the prince of the land himself due to the division of the state and increasingly large demands of the land's inhabitants (land defence) that were (in addition to the prince of the land) a strong economic factor. Hence, they were frequently $»$ a state within a state « (Obersteiner, 1993: 78). Financial development and finance are an important factor in the formation of the structure of the administrative machinery, which depends on the administration and governance development, and on the time in which it is formed. The prince of the land was also aware of this factor. Due to the common good, he, as a legislator, had reached for the norm very early. It was called the Police Orders at the Beginning of Modern Times (Brauneder, 1996: 308; compare modernity with the relevant literature: Brezovnik, 2008: 98).

Subdivisions, powers, and the consequences thereof are reflected in the common good as an excuse for all the interventions in the legal, economic, social, religious, and cultural life of an individual in the historical land of Styria. The land as a framework, in which individual subdivisions were formed from territory, quarters, state administrative units, and from the predecessors of modern municipalities, is an important factor in the life of an individual. In the chapters below, I first deal with the common good as one of the motive powers of subdividing. Then I describe the concept of territory (land), subdivisions and the reasons for their formation, the significance of subdivisions and their consequences ${ }^{4}$ for those for whom subdivisions were intended. 


\section{The Common Good as the Highest End of Di visions, and Jurisdiction}

Jurisdiction or jurisdictio (as defined by the Styrian court orders, and as it is stated by Beckmann) is the competence of a certain office in administrative and judicial matters ${ }^{5}$ depending on the social status of the service users (forum competens in causa controversa), and on the matter or purpose desired by the user (Beckmann, 1688: 217-220; Weitzel, 1998: 1815). The wilful promotion of the common good resulted in police orders (from "politeia") that formed the basis for the creation of administrative offices. They had their start in the awareness of the rulers that they were "ad communem omnium civium salutem, \& conservationem dienlich" (Beckmann, 1688: 336), or as Emperor Franz I said in the 1793 Rescript that he would provide for the general welfare of his subjects - Unterthanen Wohlstand and the homeland affairs - des Vaterlandes Nutzen und Angelegenheiten (Rescript, 1793: 3). This helps understand the Decree and Rescript issued by Emperor Franz II. With the Court Office Decree of 9 March 1792 and with the Court Chamber Decree of 12 March 1792, the Emperor, in his inaugural address, released the state officials from the obligation to take the usual oath to the new ruler by confirming their full trust, loyalty, and total commitment to him. The Emperor was convinced that officials would continue to steadfastly, faithfully, and diligently do their clerical work as before. ${ }^{6} \mathrm{He}$ was aware of the fact that prosperity of all citizens (subjects) depends on good governance. Therefore, he required of all instances that they should strive above all to achieve welfare and to look after homeland affairs. And only then could they take a formal oath. ${ }^{7}$ In accordance with this, the inaugural Rescript of Emperor Franz II, which is about a specific state function, needs to be noted. In the light of legal history, it used to represent carrying out the purposes of the state (the welfare of subjects Unterthanen Wohlstand and homeland affairs - des Vaterlandes Nutzen und Angelegenheiten). During the period of the state administration development, implementation of laws was added to them. The dependent offices bound by official instructions executed laws (Brauneder, 2005: 17).

If we consider Emperor Franz II as the forerunner of the comprehension of Servitutio iuris publici, we can say that the distinction between constitutional and administrative law occurred only after the separation of the legislative functions of the Parliament from the monarchic executive power (Stolleis, 1998: 883). In his handbook, Mayerhofer distinguishes between constitutional and administrative law. In his view, constitutionality represents "the organisation of state power, administration, and the organised state power activities. The constitutional legislation provides the state organism; administrative legislation lays down the functioning of the state organism. Thus, it represents all the norms that refer to the state administrative activities." (Mayerhofer, 1896: 918). 
Besides all this, we must not overlook the territory because no subdivision can be carried out without it. Throughout history, the Ruler's sovereignty has been formed in the very territory. Grafenauer believes that sterritory (note by the author) is an essential constituent element « because »it represents the starting point, foundation, and the central issue when a certain subdivision is formed (Grafenauer, 2000: 46). Brauneder's view is entirely identical to it. However, he elaborates on it by saying that a land is 'the state that is institutionally organised on a large area ("institutioneller Flächenstaat") (Brauneder, 2005: 58). Territory is thus a space in which a solid construction of offices exists. Nevertheless, the historical experience viewed from the perspective of the strength of institutions indicates otherwise. So, the aspect of territoriality is fully justified. The very problems experienced by individual power holders show that. One of them is the request filed by Janez from Žusm. He was a feudal estate and Land Court administrator at Konjice in the 15 th century. In 1478, he referred a request to Ferdinand, the Prince of the Land. Janez asked the Prince to lay down the area in which he wanted to exercise the jurisdiction of the Land Court. In other words, he was the official with jurisdiction, but with no space in which he would exercise jurisdiction. The Prince of the Land replied that he should adhere to the primitive parish borders of Konjice (Holcman, 2000: 10). When looking at the subdivisions of the Land of Styria, we shall find out that ecclesiastical subdivisions are also important for most land subdivisions. Therefore, we need to take quotes from the Code of Canon Law from 1917. In Canon 216, the Code mentions territory dimension as an important factor of the ecclesiastical organisation. It is particularly important in border disputes. It proposes various procedures to settle disputes, e.g., solutions by using documents /according to which the dispute could be resolved «, judge-conducted settlement procedure, or acting on the principle of "in pari causa melior conditio possidentis". It mentions the decision of the Roman Rota of 31 January 1919 (Decisiones seu Sententiae XI, 1 ff), (Code, 1944: 91-92, note No. 4). Regarding the ecclesiastical subdivision, it is certainly true that the organisation of the Catholic Church in Slovenia or within the historical Land of Styria is the reflection of the situation within the Church community characteristic of the Central European Space (Kolar, 2008: 5). ${ }^{7}$ This statement also applies to subdividing the historical Land of Styria, which was particularly evident in the 18 th century because there was no village that would be a complete administrative unit. Even so, there were peasants (subjects) who were subject to different landlords, and thus to various offices (Schopf, 1845: $11 \mathrm{c}^{8}$ ).

\section{Territory, "Terra", "Land"}

When talking about administrative subdivisions and, consequently, about jurisdiction, we cannot ignore the concept of territory. Being a legal-historical term viewed from the historical perspective, territory is a terminus technicus for uniformity and integrity of a sovereign state (Brauneder, 2005: 58). To make 
illustration easier, some examples need to be given. And to highlight them, a general example of the Holy Roman Empire or an example of a historical land can be used. It was of paramount importance to the latter whether its borders were established or natural boundaries were taken into account. This phenomenon must particularly be monitored during formation of the historical Land of Styria where the border was unclear at certain places, i.e., especially in those cases where the power (primarily the power of land courts) reached beyond the natural borders represented even today primarily by streams or changed streams (Straka, 1978: 7, notes 1 and 2). The disputes, resulted from the undetermined borders (they are also anticipated by the aforementioned Code of Canon Law), led to drawing up documents and to creating legal terminology. The Georgenberg Privilege of 1186, being the Constitutional Charter of the historical Land of Styria, represents a legal source, on the basis of which we can ascertain the formation, later development, and expansion of the territory, and secondly, the rights and liberties in this territory were written in it (compare also the formation of the historical Land of Austria - privilegium Minus, Fichtenau, 1958). Institutions are closely associated with liberties and rights - "terra" becomes "the state that is institutionally organised on a large area" ("institutioneller Flächenstaat").

What does the 1186 privilege actually bring? When determining the territory, it simultaneously determines the power holder (iurisdictio), and positively restricts or allows his jurisdiction (Duke Otokar, prince as a power holder, and his people over which he has power and for whom he issues this document - Otakar, Herzog von Steier ... auf das Wohl der Unseren bedacht) (Spreitzhofer, 1986: 13). To explain this example, we can use Bartolus's interpretation and response to the question frequently asked in the Middle Ages (utrum iurisdictio cohaereat territorio). It ascertains that the power is not only the factual feature, but it is always linked to a person, and thus also to the territory. This implies that, according to Willoweit, jurisdiction (iurisdictio) is an essential component of the seigniorial power which emphasizes its significance in the territorial delimitation: "...fines tribuunt Principi ius territorii, ut intra illud constitutum ad eum spectet, alles was darinen gelegen und bekraist ..." (Willoweit, 1998: 149). In forming the historical Land of Styria, this aspect is particularly highlighted. It continues by establishing its own institutions (e.g., judiciary: $\S 8$ : "Lis exorta vel altercatio super quolibet negocio inter Stirenses non campione, sed probabilium et certarum personarum credibili dirimatur testimonio" - If a conflict or disagreement about a particular matter occurred between the Styrians, no duel should decide on this, but the testimony of experienced and reliable men. They should decide on the dispute or disagreement). 


\section{The Boundaries of Parishes - the Basis for the Formation of Subdi visions}

If Kolar ascertains that the organisation of the Catholic Church in Slovenia is the result of the situation in the Christian communities of Central Europe (Kolar, 2008: 3), we can find out through Pirchegger that pre-Joseph parishes were of crucial importance in determining the land court boundaries (Holcman, 2000: 10), and the quarter and district boundaries

(Pirchegger, 1912: 101). Pirchegger discovered that administrative boundaries matched pre-Joseph parishes in most cases. He used some very old maps with marked delimitations. By means of them, he found one of the oldest divisions that ran along the Drava river, i.e., the division between Salzburg and Aquileia at the beginning of the ninth century (Charles the Great, 811). It was based on the administrative boundaries that had their start in numerous subdivisions in 1770 . On the basis of this information and by means of the sources used by Joseph II for formation of parishes in 1782, he found delimitations up to the year 1500, or up to the 13th century when dioceses and primitive parishes were established in the area of the historical Land of Styria (cf. Straka, 1978: pp. 9, note 3). ${ }^{10}$

The creation of the subsequent administration coincides with the Emperor Joseph II's regulation of the Church, primarily the formation of the Emperor Joseph II parishes and the possibility of creating the counting offices in 1770. Emperor Joseph II set a new arrangement by issuing his Patent on 24 October 1783.

It is interesting to note that as late as the 15 th century, a parish was used as a basis for determining the location of a specific place. And the historical Land of Styria was divided between the two archdioceses in Salzburg and Aquileia as late as 1445.

\section{Quarter Boundaries}

The Turkish threat and the land defence led to the division of the land separately from the ecclesiastical organisation. In mid-October 1462, the representatives of provincial estates met in Leibnitz to divide the land into quarters (Oberstiner, 1993: 78, note 1). Styria was divided into five quarters that were entered in the property book in 1495. Tax books and visitation protocols allow the reconstruction of the quarter boundaries that were described in a descriptive manner. The following words were used: on this side and on the other side, below and above ("enhalb der Piberalm, dieshalb der Piberalm, enhalb der Drau, herab vom Mürztale"). The land was divided according to the natural realities. The upper mark reached to the Gleinalpe-Fischbacher Alpe line. The lower mark reached to the Drava river. It was divided into two quarters, and they were divided by the 
Mura river. The area legally pertained to the Aquileia Patriarchate south of the Drava river.

As already mentioned, there were five quarters: Judenburško, Muriško, Vorau, the quarter between the rivers Mura and Drava, and the Celje quarter or the quarter beyond the Drava river.

The first changes of this distribution occurred towards the end of the 16th century. The parishes again played a crusial role, and the changes that happened in 1677 and 1700 were also significant. The crucial role was played by Seckau Diocese. Today, it is known as Graz Diocese.

\section{District Boundaries}

It is clear that the division of the land into quarters (the division was carried out for defence purposes in the 15th century) was not appropriate to take administrative tasks. The colonisation of Styria was very different from the north to the south. It allowed the formation of differently populated areas. The changes which happened towards the end of the 17th century and at the beginning of the 18th century took away the southern parts of the Upper Styrian quarters. They caused some efforts for new divisions. However, only Empress Maria Theresa's reign led to the changes in the administrative divisions.

As already mentioned, the reign of Empress Maria Theresa led to the administration development. Judiciary was separately organised and subject to the Supreme Court (Oberste Justizstelle). It remained in the hands of the land courts in rural areas. The area division was presented on the map prepared by MellPirchegger in 1906 (Historischer Atlas der österreichischen Alpenländer, published by the Academy of Sciences in Vienna. Landgerichtskarte. Steiermark, bearbeitet von Anton Mell und Hans Pirchegger, Wien 1906). Numerous offices for administration were established. A team and a chamber emerged at the land level. They were renamed into Guberniums in 1763 (Straka, 1978: 16., compare also: Handbooks, 1988: 76). The connection between the professional and state administration was set up so that the president of the gubernium was also the provincial governor (e.g., Franz Anton grof von Khevenhüller=Metsch, governor and provincial governor in 1782).

District offices, established in rural areas in 1748, certainly represent the most significant shift in the direction of the administration having a control or passive role (having an active role in divisions during the time of Emperor Joseph II). They were headed by district governors. Being civil servants, they are responsible for control over quarters. The establishment of district offices led to the situation where it was necessary to re-regulate the quarter distribution which was adopted 
and confirmed in January 1749. According to Straka, the new distribution was not well made because it occurred at the green table by taking into account the maps that were made by Homann, Lotter, and Dietell. They all had their basis in the Vischer topography (Straka, 1978: 16).

An absolutely accurate determination of district borders was enabled only by the census in 1770 when the houses were simultaneously numbered, and a special census of the male population capable of recruitment was taken. The census was taken in districts. It is interesting to note (this was discovered by Pirchegger) that the boundaries of counting divisions (with very few exceptions) matched with the parish boundaries (Pirchegger, 1912, 56-66). The last testified use of the parish boundaries to regulate borders dates from 1783. During that time, counting offices, recruitment districts, and the Emperor Joseph II tax municipalities existed. The latter used parish divisions as a basis for distribution.

\section{Emperor Joseph II's Patent of 24 December 1782}

If Empress Maria Theresa established districts (in 1748) that had primarily a passive role in administration, Emperor Joseph II (in his Patent of 24 December 1782) transformed the districts into active offices. Under 25 items, he determined the office powers and called them the first administrative instance above which only the Gubernium was. The instructions, which are part of the patent, give full details of all the powers and provides forms with which the district officials reported on the situation in district offices.

\section{Counting Offices from the Year 1770}

After regulating the state administrative units and district offices, the middle-level administration was regulated. The state administrative units were too large from the aspects of territory and population. Therefore, smaller, more transparent and manageable territorial units had to be established. For their establishment in rural areas within districts, feudal estates and even parishes were the most appropriate ones. However, house numbering and the census soon showed that feudal estate and parishes did not meet the requirements of the administration. In Styria there were no homogenous feudal estates, and there were villages in which nearly each peasant was subject to other landlords (Schopf, 1845: 11c).

At this level, administration reorganisation went hand in hand with the reorganisation of the Army which took place in 1769. Recruitment and conscription were carried out under the general military obligation. For this purpose, it was necessary to know the number of people in each village. Therefore, the Empress issued two patents on 10 March 1770. With the first patent, she ordered the district commissioners and military officers to take a 
census of all the population together with draught animals, and to number the houses. The second patent announced her intention to introduce a regular and ongoing recruitment system, and own recruitment districts for individual regiments (the recruitment place Negova supplemented the infantry regiment of the Count Kinsky with conscripts (Holcman, 2004: 75 ${ }^{11}$ )) (Straka, 1968: 138-150). On the basis of these two patents, the establishment of numerous detachments and recruitment districts was set.

House numbering was part of the census, which was carried out in 1770. It was a double census: ex parte civili and ex parte militari. The district commissioners acted according to the Status Animarum. Parish priests were obliged to keep it. In accordance with this, house numbering and military counting of men capable of defending their homeland were done. Thus, the pre-Joseph parishes were the basis for the administrative division.

While counting the men for conscription purposes and the results prepared by officers were very exact (an accurate census of male population; data on house numbers, and counting the souls were not very accurate). The census was taken within parish boundaries to number the houses with regard to the parishes to which they belonged. If a certain place or village had several parishes, the commanding officer first numbered the houses and then counted only the parishioners from the parish assigned to him.

Regarding house numbering, we today ask ourselves what houses had to be numbered. On this, the instructions from the patent, published in 1804, have been preserved. Prior to that period, lists contain information on inhabited and uninhabited houses (the lists made in the Maribor and Celje districts show that the uninhabited houses in the tenants' vineyards were also counted). As a result, the patent of 1804 provides under Article 3 that the houses, intended for people's flats, must be numbered ("alle Gebäude, welche zur Wohnung der Menschen bestimmt").

Therefore, a counting office was the sum of the houses within a territorial unit, which was usually a village. There are three categories of a territorial unit: a town, a market town, and a village. A village was least clearly defined because the decision was left to the officer who was responsible for taking the census. This was a problem particularly in the case of dispersed settlement. That is why there were numerous detachments of all possible sizes

(Straka, 1978: 21). 


\section{Recrui tment Districts}

Recruitment districts were not something permanent, but being primary administrative units, they were always changing. Their number is known from 1826 when they were entered as tax districts in the land registry general map.

Empress Maria Theresa introduced recruitment districts as part of the army reorganisation.

In the March Patent from 1770, the Empress spoke of introducing a permanent recruitment system, and of own recruiting regiments. After completion of counting, she again announced the division of the land into recruitment districts in two March patents in 1771 (Pirchegger, 1912: 1912). Although the Patents were published, vagueness items frequently occurred. Only the regulation of 1773 determined certain parishes as recruitment districts for individual units, requiring that the officials who were simultaneously administrators of feudal estates should necessarily attend the military conscription. Thus, a connection was established between newly established districts and feudal estates. However, due to high fragmentation of feudal estates and subjects, the second command was practically not performable in Styria. They found a way out of this situation by transferring recruitment jobs to the feudal estate that had most subjects in its parish, or its location was favourable for the execution of commands. So, this task was restricted to larger feudal estates. The patent from 1777 determined to which regiment the conscripts should be sent. The feudal estate officials were employed as "politische Werbbezirkskomisäre" (administrative district conscription commissioners) (Pirchegger, 1912: 72-81).

\section{Conclusion}

Through the history, the common good has been one of the essential motive powers. On the other hand, territory represents the concept of marking the territorial dimension that leads to subdivisions - to the powers of the institutionally organised space. The establishment of the land did not only represent the space for the institutionalisation of the political, economic, cultural, religious and other goals of the state, but also the welfare of an inhabitant.

The quarters as a result of the Turkish threat mean the organisational form that originally served the purpose of defence. They also represent an option for the provincial governor to transparently manage the human and economic resources. This aspect is especially reflected in district offices, established in 1750, in counting offices, recruitment districts, and in district lords that are immediate forerunners of municipalities. The district office initially represented mere control. During the reign of Joseph II, it became an active factor in managing 
administrative affairs of a certain space. For this, at least certain development is needed. In the first place, it represents the division of the legislative and administrative branches of government. Then it represents the awareness that ius eminens fully establishes itself with the presence of loyal officials at all levels of the divided administration.

In 1770, the census implies not only ascertaining the state of affairs, but also the state of the population, the state of the male population, and the state of the immovable property that can indirectly be a fiscal factor. Here status animarum, led by local priests for their parishioners, played a special role.

The subdivision has a special place here. It has been used by the Roman Catholic Church throughout the history. Although it is about an autonomous division, it is actually controlled. This control is shown in advocacies (Vogteirecht) and in the intervention of individuals in personal affairs of the Church. One conclusion is essential for us: pragmatism of each ruler in forming divisions. This can be pursued throughout the history of the historic Land of Styria at all levels: from quarters to tax municipalities. In this regard, the conduct of authorities can also be a model for modern land use. One of them took place some time ago when the Roman Catholic Church regulated the regions (dioceses) of the Slovene Ecclesiastical Province to the credit of its believers.

We may ask ourselves: Where is here the welfare of the citizens of the Republic of Slovenia, if we know that the current Government and all its predecessors have not been able to agree on the subdivision of the state, which is one of the key conditions for subsidies from the funds of the European Union whose member is the Republic of Slovenia?

\section{Notes}

${ }^{1}$ Compare the Decree and Rescript of Emperor Franz II from the year 1793 (Decree of 9 March 1793 in Rescript of 2 March 1793 talk about the welfare of subjects - Unterthanen Wohlstand in zadevah domovine - des Vaterlandes Nutzen und Angelegenheiten).

${ }^{2}$ In this context, compare Marko Kambič: 2008, pp. 475-486, primarily the chapter Local Autonomy and Self-Government - basic distinctions, pp. 477-478, and relevant literature and sources.

${ }^{3}$ On the modern role of power holders, primarily on elections and powers of the original power holders - the parliament and people established in practice in modern Slovenian political arena with all the relevant literature, see:Jurij Toplak, The parliamentary election in Slovenia, October 2004. Electoral Studies xx (2006) pp. 1-6.

${ }^{4}$ On the consequences of the formation of such a community, see Kambič, 2008: 459-488, and the relevant literature and sources.

${ }^{5}$ Beckman, 1688, pp. 217: "Die Instanz, in Jure Statutario, ist eigentlich nichts anders / als forum competens, alwo ain jeder / der diesen / oder jenen foro, und instanz, vel ratione 
personae, (in civilibus, criminalibus, militaribus, Ecclesiasticis, feudalibus \&c.) ... Steyrische Gerichts=Ordnung, art. I. \& 19, v: Steyrischer Landhandfest, fol. 62; pp. 218: "Ex dictis patet, daß man in personal-Spruchen / muß wohl beobachtet / den Stand / und die Qualität der beklagten Personen / ob es ein Herr / und Landmann / ein Ge istlicher / ein Soldat / Bürger oder Bauer sey / damit ein jeder / vor seiner Obrigkeit / competenter beklagt werde;"

${ }^{6}$ Prim.: Dekret der Hofkanzley vom 9. März, an sämmtliche Länderstellen, und der Hofkammer vom 12. März, an sämmtliche ihr untergeordnete Behörden (1793) v: Sr. k.k. Majestät Franz des zweyten politische Gesetze und Verordnungen für die Oesterreichischen, Böhmischen und Galizischen Erbländer. (Wien: mit von Kurtzbeckischen Schriften, 1. Band, pp. 5-6): "... von Ablegung einer neuen Eidespflicht gänzlich zu entheben geruhet, und hiervon dieselben mit dem Beysatze zu verständigen befohlen haben, Se. Maj. verstehen sich, daß alle Beamte in ihrem Eifer und ihrer Treue auch ferner, wie bisher, unverrückt fortfahren würden; ..."

${ }^{7}$ Compare: Reskript vom 2. März, an sämmtlic he Länderstellen, (1793) v: Sr. k.k. Majestät Franz des zweyten politische Gesetze und Verordnungen für die Oesterreichischen, Böhmischen und Galizischen Erbländer. (Wien: mit von Kurtzbeckischen Schriften, 1. Band, pp. 2-3.): "... damit Unserer getreuen Länder und gehorsamsten Unterthanen Wohlstand durch gute Regierung befördert und erhalten werde, ... So haben Wir Euch insgesamt mit allen Euch untergeordneten Dikasterien, Instanzen, wie auch dem unterstehenden Personale, ... befehlen Euch auch hiermit gnädigst, ... des Vaterlandes Nutzen und Ange legenheiten Euch eifrigst anempfohlen seyn lassen, ...

${ }^{8}$ Practice in the modern organisation of the Catholic Church in Slovenia, compare: Kolar 2008: 3-39.

9 "Da in Steiermark die Unterthanen der Herrschaften sehr zerstreut liegen, in manchem Dorfe oft 10, auch mehr Grundherrschaften einschreiten, so ist a. h. Orts mittels des Patentes vom 7. März 1775 die Aufforderung an alle Gültenbesitzer wegen Bewerkstelligung der Vereinigung der gemischten Unterthanen, durch Kauf oder Tausch erfolgt..."

${ }^{10}$ Pirchegger ascertained that in 1218 , Styria had 41 primitive parishes; three of them had their seats outside the land boundaries; in 1500, there were already 164 primitive parishes, compare Pirchegger, 1940: pp. 29-38.

${ }^{11}$ Message from the parish of St Joseph from Piacenza of 29 July 1831; on the death of corporal Jožef Petovar, born at Ilijaševci, Negova feudal estate: Regional Archives Maribor, Negova feudal estate, Sig. 1911011, AŠ 46/1833. Jožef Petovar served as corporal in Kinsky regiment, No. 47, the first battalion, died of typhoid fever on 25 July 1831, at half past five in the evening.

\section{References}

Appelt, H. (1976) Privilegium minus. Das staufische Kaisertum und die Babenberger in Österreich (Wien-Köln-Graz: Böhlau Quellenbücher).

Beckmann, N. (1688) Idea Juris Statutarii et Consuetudinarii Stiriaci et Austriaci cum Jure Romano collati. (Graecii, Sumtibus Autoris).

Brauneder, W. (2005) Österreichische Verfassungsgeschichte (Wien: MANZ Studienbuch). 
Brauneder W. (1996) Die Policeygesetzgebung in den österreichischen Ländern des 16. Jahrhunderts: Derzeitiger Forschungsstand und Perspektiven, Policey im Europa der Frühen Neuzeit, pp. 299-316.

Brezovnik, B. (2008) Decentralisation in Theory and Practice, Lex localis - Journal of Local Self-Government, 6 (1), pp. 87-103.

Dekret der Hofkanzley vom 9. März, an sämmtliche Länderstellen, und der Hofkammer vom 12. März, an sämmtliche ihr untergeordnete Behörden (1793), v: Sr. k. k. Majestät Franz des zweyten politische Gesetze und Verordnungen für die Oesterreichischen, Böhmischen und Galizischen Erbländer. (Wien: mit von Kurtzbeckischen Schriften, 1. Band), pp. 5-6.

Dilcher, G (1998) Verwaltung II, Städte (Berlin: Erich Schmidt Verlag, HRG V) pp. 871875.

Fichtenau, H. (1958) Von der Mark zum Herzogtum. Grundlagen und Sinn des "Privilegium Minus" für Österreicht (München: Verlag für Geschichte und Politik).

Grafenauer, B. (2000) Lokalna samouprava na slovenskem, Teritorialno-organizacijske strukture (Maribor: Univerza v Mariboru, Pravna fakulteta).

Holc man, B. (2000) Deželskosodna oblast v Konjicah (Gonobitz), nastanek in dokončno izoblikovanje. (Slovenske Konjice: Zbornik Konjice z okolico) pp. 5-21.

Holcman, B. (2004) Patrimonialno sodstvo $v$ obdobju pravnega (razsvetljenega) absolutizma (ob primeru zemljiškega gospostva Negova) (Ljubljana: Univerza v Ljubljani, Filozofska fakulteta).

Kambič, M. (2008) Self-government and Autonomy of Statutory Municipalities in the Light of Historical Sources for the "Provincial Capital of Ljubljana", Lex localis Journal of Local Self-governement, 6 (4), pp 459-488.

Keller, C. (1998) Verwaltungsgerichtsbarkeit, in: Erler A. (ed.), Kaufmann E. (ed.), Werkmüller D. (ed.), Handwörterbuch zur Deutschen Rechtsgeschichte, vol. V., pp. 879883.

Kolar, B. (2008) Basic Characteristics of the Development of Organisational Structures of the Catholic Church in Slovenia, Lex localis - Journal of Local Self-government, 6 (1), pp. 3-39.

Landhanduest (1583) Des Löblichen Hertzogthumbs Steyr / darinnen Keyserliche / Königliche / vnd Landtsfürstliche Freyhaiten / Statuta / Landts gebreuch / vnd ander Satz: und Ordnungen / nach lengs begriffen. Auff sondern beuelch vnd der ordnung einer Ersamen Löblichen Landstschafft obbemelts Herzogthumbs Steyer / auß den alten gefertigten Originaln flissig abgeschriben / vnd ordentlich Collationiert / folgendts von newen Getruckt / etc. Inhalt diser gentzen Landthandvest / am folgenden Plat / Artickelwe is verzaichnet zusehen. (Graetz: Anno M. D. LXXXIII.).

Mayrhofer Ernst (1896) Handbuch für den politischen Verwaltungsdienst in den im Reichsrathe vertretenen königreichen und Ländern mit besonderer Berücksichtigung der diesen Ländern gemeinsamen Gesetze und Verordnungen (Wien: Manz'sche k.u.k. Hof-Verlags- und Universitäts-Buchhandlund, Band 2, Fünfte, vermehrte und verbesserte Auflage, Redigiert und herausge geben von Graf Anton Pace).

Mell, A. (1929) Grundriß der Verfassungs- und Verwaltungsgeschichte des Landes Steiermark (Graz, Wien, Leipzig:Verlag der Universitäts-Buchhandlung Leuschner \& Lubensky).

Mitteis, H. \& Liebereich, H. (1992) Deutsche Rechtsgeschichte, Ein Studienbuch (München: C.H.Beck'sche Verlagsbuchhandlung). 

Administration Office: An Example of the Historical Land of Styria from 1186 to 1850

Obersteiner, G. P. (1993) Die steirischen Bezirkshauptmannschaften 1868 bis 1918, Mitteilungen des Steiermärkischen Landesarchivs, 42/43; pp. 77-98.

Patent de dato 24. Decemb. 1782.(1782) Die Umstaltung der Kreisämter aus blos Exequierenden in wirkende Stellen betreffend. (Pokrajinski arhiv Maribor, Normalia, Zbirka patentov in kurend).

Pirchegger H. (1912) Die Pfarren als Grundlage der politisch-militärische Einteilung der Steiermark (Wien: Archiv für österreichische Geschichte 102/I).

Pirchegger, H. (1940) Die kirchliche Einteilung der Steiermark vor 1783. Erläuterunge zum Historischen Atlas der österreichischen Alpenländer (Wien: Akademie der Wissenschaften in Wien. II. Die Kirchen- und Grafschaftskarte. 1. Steiermark).

Priročniki in karte o organizacijski strukturi (uprave) do leta 1918 (1988)/Handbücher und Karten zur Verwaltungsstruktur bis 1918; Manuali e carte sulle strutture amministative fino al 1918/, izd. Jože Žontar et. al, (Gradec, Celovec, Ljubljana, Gorica, Trst).

Rakočevič S. (1991) Državna uprava, vloga, položaj, organizacija, delovanje (Ljubljana: Uradni list Republike Slovenije).

Reskript vom 2. März, an sämmtliche Länderstellen, (1793) v: Sr. k.k. Majestät Franz des zweyten politische Gesetze und Verordnungen für die Oesterreichischen, Böhmischen und Galizischen Erbländer. (Wien: mit von Kurtzbeckischen Schriften, 1. Band), pp. 23.

Schmutz, C. (1822) Historisch topographisches Lexicon von Steyermark vol. I-IV (Graz: Kienreich).

Schopf, F. Jospeh (1845) Die Grundobrigkeiten im Lande Steiermark, deren Wirkungskreis und Amtshandlungen (Graz: Kienreich).

Spreitzhofer, K. (1986) Georgenberger Handfeste. Entstehung und Folgen der ersten Verfassungsurkunde der Steiermark (Graz-Wien-Köln: Styria).

Stolle is, M. (1998) Verwaltungsrechtswissenschaft (Berlin: Erich Schmidt Verlag), pp. 883-886.

Straka, M. (1960) Die Seelenzählung des Jahres 1754 in der Steiermark, ZHVSt, 51, pp. 95117.

Straka, M. (1961) Die Bevölkerungsentwicklung der Steiermark vin 1528 bis 1782 auf Grund der Kommunikantenzählungen, ZHVSt, 52, pp. 3-53.

Straka, M. (1961) Die Pfarrenzählung des Jahres 1782 in der Steiermark. Beitrag zur Erforschung steierischer Geschichtsquellen, Historsiches Verein für Steiermark, 48 nеие Folge, pp. 12-14.

Straka, M. (1961) Die Pfarrenzählung des Jahres 1782 in der Steiermark. Beiträge zur Erforschung steirischer Geshichtsquellen, Historsiches Verein für Steiermark Neue Folge Heft, 16.

Straka, M. (1962) Studie über die Verwendbarkeit der Häuserzählungen des 15. Jahrhunderts zur Bestimmung der Seelenzahl, ZHVSt, 53, pp. 45-52.

Straka, M. (1964) Beiträge zur Bevölkerungs- und Sozialgeschichte der Steiermark im 18. Jahrhundert, ZHVSt, 55, pp. 47.

Straka, M. (1965) Die Rekrutierung für den Siebenjährigen Krieg aus der Steiermark, ZHVSt 61, pp. 43-61.

Straka, M. (1967) Die Ortschaften- und Seelenzählung von 1761 in der Steiermark. Aus den Anfängen der österreichischen Statistik, ZHVSt-Sonderband, 14, pp. 82-106.

Straka, M. (1968) Die einrichtung der Numerierungsabschnitte in der Steiermark 1770 als Vorstufe der Steuergemeinden, ZHVSt-Sonderband, 16, pp. 138-150. 
Straka, M. (1978) Verwaltungsgrenzen und Bevölkerungsentwicklung in der Steiermark 1770-1850, Forschungen zur geschichtlichen Landeskunde der Steiermark (Graz: Historische Landeskommiss ion für Ste iermark).

Toplak, J. (2006) The parliamentary election in Slovenia, October 2004, Electoral Studies, 25 (4), pp. 825-831.

Weitzel J. (1998) Zuständigkeit der Gerichte, in: Erler A. (ed.), Kaufmann E. (ed.), Werkmüller D. (ed.), Handwörterbuch zur Deutschen Rechtsgeschichte, vol. V., pp. 1815-1817).

Willoweit, D. (1998) Territorium, in: Erler A. (ed.), Kaufmann E. (ed.), Werkmüller D. (ed.), Handwörterbuch zur Deutschen Rechtsgeschichte, vol. V., pp. 149-151.

Willoweit, D. (1998) Verwaltung I: Reich und Territorrium, in: Erler A. (ed.), Kaufmann E. (ed.), Werkmüller D. (ed.), Handwörterbuch zur Deutschen Rechtsgeschichte, vol. V., pp. 864-871.

Zakonik Cerkvenega prava, Codex iuris canonici (1944) (Ljubljana: Sestavljen po ukazu papeža Pija X. in razglašen z oblastjo papeža Benedikta XV., prevedel in z novimi odloki priredil Alojzij Odar).

Zakonik Cerkvenega prava, Codex iuris canonici (1983) (Ljubljana: Nadškofijski ordinariat Ljubljana). 